The Geneva Papers on Risk and Insurance, 23 (No. 87, April 1998), 152-168

\title{
Long Tail (Liability) Risks and Claims Made Policies
}

\author{
by Jaap Spier*
}

\section{Introduction ${ }^{1}$}

Insurers are sounding the alarm ever more. They express serious concern about the trends in tort liability law (the advancing of strict liability), the increasing claims consciousness, the skyrocketing claims, the growing time elapsing between the moment where the damage causing event takes place, the occurrence of the damage and the claim is brought ${ }^{2}$ and the decreasing predictability of the future.

Claims made-policies are often deemed to be the only solution to keep the floodgates shut. However, such policies incur fierce criticism by legislators, courts and doctrine.

This begs the most intriguing question: should claims made-policies be damned to hell? Is it possible to find a compromise between the interests of insurers and insured (or victims)? And, should we strive for such a compomise?

\section{Fiction or reality?}

Are the above mentioned one-liners based on facts or are they merely fairy tales? Leaving the future aside for a while, it is difficult to answer this question, let alone to go into any detail; that would go far beyond the purpose of this contribution. To the best of my knowledge accessible statistics hardly exist. Insurers are inclined to keep them secret.

* Attorney-General at the Supreme Court of the Netherlands and Professor of Private Law at the University of Tilburg, The Netherlands

${ }^{1}$ This contribution is largely based on a comparative study on claims made policies executed by my Tilburg colleague Olav Haazen and myself. This study and our many discussions resulted in a book: Aansprakelijkheidsverzekeringen op claims made-grondslag, Kluwer, Deventer 1996.

${ }^{2}$ Mainly in relation to occupational diseases, environmental and product liability. 
The American Bar Association put it as follows: “(...) reliable data are not available even for the most basic questions, such as trends in frequency of tort litigation or severity of tort judgements." 3

This does not mean that statistics are not available at all. Various publications reveal figures, many articles shed light on specific topics (often case law). Research has been done in the Netherlands. It shows an increasing claim consciousness in several areas and a considerable increase in the total amounts to be paid ${ }^{4}$.

In their yearly CEA meetings, the national Associations exchanged a lot of useful be it often not very detailed - information. It seems recommendable to make it publicly available.

We do not know what lies ahead of us. Yet, it has been suggested that prospects are far from blooming. This expectation might well turn out to be true. Reality might even be less prosperous than many are inclined to believe.

Just to give some examples: environmental, D \& $\mathrm{O}$ and professional liability, occupational diseases $^{5}$. It does not seems unlikely that product liability will also be brought to life (e.g. in connection with computer screens, keyboards, portable telephones, drugs, cigarettes, etcetera). New - and often more far reaching - case law, often has a retroactive effect; the consequences could well be immense.

In relation to occupational diseases, Dutch and German research reveals a strong indication of a rather alarming future ${ }^{6}$. The same is true for Dutch statistics concerning professional liability. D\&O claims also show a rather dramatic increase. There is no reason to believe that these developments will be confined to the Netherlands.

\section{Claims made policies in Europe}

In Europe claims made-policies are still relatively rare. It is doubtful that insurers are in the process of implementing them on a larger scale.

The attached overview by Münchener Rück provides a significant amount of information. The majority of Dutch insurers will have issued claims made GLI policies as of 1997; professional liability and non accidental environmental liability were already based on this phenomenon.

French, Spanish and Belgian insurers stress the importance of claims made-policies. International brokers are said to doubt whether the same is true on a more general European scale.

\footnotetext{
${ }^{3} \mathrm{ABA}$-report of the commission to improve the liability system page $88 / 89$. pp $7 \mathrm{ff}$.

${ }^{4}$ See for more details O.A. Haazen en J. Spier, Preadvies Nederlandse Juristen-Vereniging 1996

${ }^{5}$ I am aware of the fact that the latter are not affected by liability law in various legal systems, unless gross negligence or similar concepts can be invoked.

${ }^{6}$ See for details M.G. Faure and T. Hartlief (ed.), Verzekering en de groeiende aansprakelijkheidslast, in particular pp. $221 \mathrm{ff}$.
} 
Insurers will continue to cover all kinds of risks on a loss occurrence-basis if claims made-policies are not allowed by either case law or legislation.

The same situation applies to France, Belgium and Spain. The pressure in the latter two countries has been effective insofar that the legislator changed the law. Claims made policies are now allowed in both countries, be it with exeptions. (See below.)

\section{Why are claims made policies so rare?}

Does the above mean that insurers actually do not fear the future? Or only that they are afraid that they will not sell other insurance products any longer if they will refrain from offering occurrence based liability policies?7 A choice between the "devil and the deep blue sea".

Theoretically speaking, one could also imagine another explanation: insurers perceive the risks and developments quite differently in the various countries. This assumption seems rather far fetched for several reasons. First, it is highly unlikely that developments (legal and factual) will stop at national borders. In a medium long period, if not earlier, they will affect (or should I say infect) other countries as well. Moreover, there will be victims all over the world, while one cannot take for granted that the law of the insured will always apply.

Finally, it is conceivable that insurers in several countries are not anxious about the future, given their positive experiences in the past. They may well be right, be it that the claims virus might well turn out to be much more contagious than they believe. Like diseases: they are not stopped by national frontiers.

If not for other reasons, it seems highly desirable to do research on the question of whether, and if so then why, the developments in some countries are so very different from those in other countries.

One cannot escape from considering these questions. For a number of reasons, claims made policies are (or, at least, might be) rather harsh for the insured; see below. Given the criticism they meet, insurers should sell their case as convincingly as possible. Stories about worrying developments will certainly be true. They may fail to have much impact if they cannot be founded on statistics. As to the future, this is clearly impossible. However, one could extrapolate the past and/or provide specific information which gives serious rise to concern.

$\mathrm{Be}$ it as it may, the reluctance of insurance companies to introduce claims made policies in the greater part of Europe could well affect claims made-conscious insurers in other countries. It is not easy to explain why claims made policies are a necessity to survive in one country, while they are not in other countries. It is even more difficult if insurers in a specific country argue that claims made policies are truly a must, but continue to issue loss occurrence-policies if claims made policies are not allowed. Research should be done as to the reasons for such behaviour.

\footnotetext{
${ }^{7}$ Instead of loss occurrence, one could also think of act committed policies. To the best of my knowledge, they have become rather obsolete, at least in the Netherlands.
} 


\section{The advantages and disadvantages of claims made-policies}

\subsection{The essence of claims made policies and gaps in the coverage}

Seen from the insurer's perspective, the most important advantage of claims made policies clearly is that he can get rid of risks he is no longer prepared to run simply by terminating or not renewing the policy.

By the same token, this is the main disavantage seen from the insured's angle. The insured may (and probably will) be faced with gaps in his insurance cover. Except for cases like non payment of the premium, change of the insured's business, a bad "claim record" due to inproper working conditions, bad control of the manufactured products or poor craftsmanship - which can be disregarded, while they do not give rise to concern seen from a general point of view - the obvious reason to terminate the contract will often be one or more of the factors mentioned above. In those cases it is highly unlikely that a subsequent insurer will be prepared to provide a retroactive coverage (for those risks). If this assumption is invalid, either the latter underestimates the risks at stake (and consequently embarks on irresponsible risks) or the former's dicision to terminate the agreement was overcautious.

It should be stressed that the same may happen if the contract is terminated by the insured, e.g. because the premiums of other insurers are more attractive. Theoretically speaking, there is less reason why the subsequent insurer would refrain from providing retroactive coverage in this scenario. Yet, insurers are concerned about the future. They consider that future developments may well affect the past and right they are. For those reasons, it seems fair to assume that they will be reluctant anyway with retroactive coverage.

\subsection{An appropriate limit of liability}

Unlike loss occurrence-policies, the applicable limits of liability are determined by the time of the claim ${ }^{8}$. Given the insured's increasing exposure, it will probably be higher than the limit at the time of the "occurrence". This is particularly important for long tailclaims.

\subsection{A lower premium}

Claims made-insurers' exposure is restricted compared with loss occurrence insurers. Consequently, the premium can be lower. This is clearly to the advantage of the insured.

However, the advantage will disappear as claims made-policies last longer. After all, long-lasting claims made-insurances provide retroactive cover, at least going back to the starting date ${ }^{\varphi}$.

The calculation of premiums will be easier for insurers. Seen from their point of view, the time lapse between act, occurrence and claim will be reduced ${ }^{10}$. They can focus on

\footnotetext{
${ }^{8}$ I leave serial clauses aside.

${ }^{9}$ Even in this case, they should be cheaper. Indeed, the insurer can avoid future risks by rescinding from the contract.

${ }^{10}$ Indeed, they do not provide retroactive coverage and their exposure for future claims will be limited, depending on the wording of the extended reporting and circumstance clauses.
} 
claims in a limited period of time, thus taking advantage of the most recent developments and the most up to date information.

\subsection{The meaning of claim is much clearer than "occurrence"}

One of the clear disadvantages of loss occurrence-policies is the fact that the meaning of "loss occurrence" is far from clear. This uncertainty is rather dangerous for insurers. Courts, especially in the United States, are inclined to interprete the wording very much to the benefit of the insured and the victim.

This problem could be solved, at least to a large extent, by a more detailed and elaborate wording. Yet, it hardly seems possible to think of a draft that would solve all the problems.

Meanwhile, this point becomes less important if claims made-policies also refer to "loss" and/or "occurrence", in that they only cover claims if the loss occurred during the running of the policy.

To some extent the same counts if the policy refers to claims arising out of a wrongful act of the insured.

For example: a manufacturer of drugs (M) puts an opiate on the market in 1990. In 2000 it turns out to cause serious damage. The incubation period is between 5 to 8 years. A is insured by I between 1993 and 2000. The policy is based on claims made - without retroactive coverage - and requires that claims arose from a wrongful act within the period of coverage.

A victim (V) sues $M$ in 2000 . It is not clear when he bought the relevant opiates. In view of the incubation period, it may be assumed that this happened between 1992 and 1995. A was covered as of 1993 . It is not clear whether or not I must pay ${ }^{11}$.

One should not be too quick to assume that this is just a farfetched example, which hardly deserves attention. Similar cases will undoubtedly appear on the scene. It would be attractive to elaborate on this topic, but this would lead us away from the even more fascinating issue at stake.

\section{Instruments to keep the effects of claims made-policies within (reasonable?) limits}

\subsection{Retroactive coverage, extended reporting period and circumstance clause}

\subsubsection{General observations}

Claims made-policies as such are not a threat to the insured. The "only" - but serious - disadvantage is the possibility that he may face a gap in his coverage. This gap will be caused by a combination of two factors: the present insurer does not provide an extended notification period nor a circumstance clause, while the subsequent insurer does not provide retroactive coverage.

${ }^{11}$ I realise, of course, that this is merely a matter of proof. The wording as such is sufficiently clear. However, this observation is far from helpful to solve the problem. 
It should be stressed that damage which already occurred or acts which have been committed may give rise to claims which will never be insured if they are known by the insured. The requirement that the insured (proposer) should have disclosed material facts and the legal consequences if he failed to do so will cause gaps anyway. Even if the insurer would retroactively cover, it will never apply to these facts.

Subsequently, measures could be taken to keep the effects of claims made-policies within bearable limits. The tools are: retroactive cover, extended notification period and a circumstance clause.

However, it is extremely unlikely that - even apart from the observation just mentioned - insurers will provide them on such a scale that gaps will be entirely avoided. If so, claims made-policies would be no use. They aim - and rightly so - to protect the insurers. This will only be achieved if the insured is left in the cold if the risks increased considerably and the damage can no longer be paid out of the premiums.

Even if an extended reporting period and a circumstance clause together with retroactive coverage would avoid gaps now, we must not take for granted that the same will be true in the (near) future. On the contrary: this will probably not be the case. The more worrying the developments (be it increasing claim consciousness or payable amounts, retroactive case law, etcetera), the less likely the insurers will (continue to) be generous in these respects in the future.

Theoretically speaking, insurers could increase premiumsto the point where no longer run substantial risks. But premiums would become so high that they would no longer be affordable. In this case whether we still face a true insurance is open to debate, because the premiums would approach the financial limits of the policies concerned.

\subsubsection{The way the instruments are actually used}

The above mentioned instruments are indeed used, either voluntary, encouraged or enforced by legislation or the courts.

Voluntary restrictions are common in several countries. In the Netherlands, insurers will probably often provide retroactive coverage; they also tend to introduce circumstance or deeming clauses and prospective notification (extended reporting period). Full retroactive coverage and 2-5 years of prospective notification is usual in France; in Denmark 2-5 years of retroactive coverage and a very limited prospective notification.

The French Supreme Court holds claims made-policies inadmissable. Nevertheless, insurers apparently continue to provide GLI policies.

Belgian law requires a certain coverage for future claims. The policy has to cover claims - not covered by a subsequent insurer - made within 36 months as of the expiration of the policy, if the damage occurred during the running thereof, or claims deriving from notified circumstances during the running of the policy ${ }^{12}$. coverages.

12 One has to bear in mind that this legislation only applies to specific liability insurance 
Spanish law requires either a retroactive coverage or a coverage for future claims of one year.

\subsection{Various policies for different premiums}

\section{a) choice between loss occurrence and claims made policies}

Theoretically speaking 13 insurers could offer a choice between a loss occurrence and a claims made-policy. In view of the imminent risks of the former, the premium will be higher. Insurers could eventually depart from worst case scenarios ${ }^{14}$ to fix the same.

The striking advantage of such a choice would be that an insured would have no reason to complain if he opted for a claims made-policy. He did so deliberately and voluntary.

However, if the exposure for specific risks like D\&O, professional liability and occupational diseases, would be too uncertain and consequently unsurmountable, loss occurrence-policies are no realistic alternative; they will probably disappear altogether. It seems likely that they will no longer be available, even not for a higher premium. After all: how to calculate the dark?

One could imagine that professional organisations or legislators would put considerable pressure on (professional organisations of) insurers to provide loss occurrence-policies, despite the above. Case law as mentioned above could also be such an incentive. Yet, insurers should not be sensitive to such pressures.

\section{b) loss occurrence insurance company}

Leaving competition law aside ${ }^{15}$, one could imagine that (inter)national insurers would establish an insurance company (The Heavenly) to issue only loss occurrencepolicies, which others apparently deem appropriate and feasible. This company should be financially safe, based on fair and equitable assumptions at the time of the policies to be issued, e.g. through guarantees from the founding insurers. As shareholders, they will get a pro rata part of the profits and do not have to share in the loss. If the optimists are correct, this insurance company win flourish. If not, it will go bankrupt. Who cares? Not the insureds, who were prepared to take that risk instead of claims made-policies which would have avoided such a catastrophe!

The solution urges the legislator or the courts opposing claims made-policies to come down on one side or the other. For the time being they get out easily. They can confine themselves to expressing doubts about the need for such policies and about the fear for the future. In other words: harping on the tune that insurers just face business as usual, so

${ }^{13}$ On the short term, loss occurrence-policies will probably be available in many countries, be it not for each type of risk.

${ }^{14}$ A rather meaningless statement, since I fail to see how they could tell fortunes. To cope with this difficulty, they might take a considerable margin, departing from the worst case scenario, as it is perceived at the time of issuing the relevant policy.

${ }^{15}$ That is perhaps why this is not just what we want. I am not a competition law specialist, but I tend to believe that this problem could be tackled. Besides, it would only play a role - if at all - if the new company were to be established by a number of insurers. Each insurer could set up a loss occurrence company in the form of a separate legal entity (PLC or Ltd, SA or SàRL, AG or GmbH). 
there would be no particular difficulty in fixing the premiums. As long as catastrophies do not appear on the scene, insurers have a hard case to fight such arguments. We cannot look into the future, while it is for up to future to show who is right. It does not seem unlikely that legislators and courts will change their mind if it would turn out that insurers were right. But, by then the damage will already have been done.

The above again stresses the need for statistics and other information.

It is difficult to believe that legislators and courts would take on the position of a loss occurrence insurance company, with no other business, let alone having to argue that supplementary funds have to be put in from other sources if it cannot meet its obligations. After all, that would be saying: insurers have to bear all the bad risks, even if they did not get premiums for it, if premiums could not be calculated (even not roughly), whereas the insured would find himself in paradise: a full coverage without proper payment.

The Heavenly will - and probably should - have to avoid bankruptcy by increasing its premiums. In a "doom" scenario - the background for claims made-policies - the increase will be most significant, to be followed by further rises in subsequent years. This would urge the insureds to make a choice between staying with the company or embarking on a cheaper claims made-policy elsewhere. In making this choice they should also wonder whether the admired Heavenly has good chances to survive!

\subsection{Claims made-policies only for specific risks}

The fear for the future seems justified in several areas. In other fields it will remain business as usual, like in case of all kinds of accidents. The question is whether the latter areas could be sufficiently well defined. If so, loss occurrence-policies would be sufficient in relation thereto. Claims made-policies are to be confined to unpredictable risks.

\subsection{Information about the meaning and consequences of claims made-policies}

An advertisement of a major Dutch insurer stated. "The risks are ours, the chances are yours".

Many insureds will be unaware of the meaning and consequences of claims madepolicies. The same may be true for other features of their policies, but they will often have less draconian effects. This ignorance will be of special importance when claims madepolicies are introduced.

Insurers should be as explicit as possible about the meaning and consequences of such policies. First, because it could well be argued that they do not comply with the reasonable expectation of the average insured ${ }^{16}$. In other words: they have to reckon with negative reactions from courts if they do not ${ }^{17}$. Second, it seems fair to inform the insured about the potentially nasty consequences.

\footnotetext{
${ }^{16}$ This may well be different for multinationals, companies represented by wellknown brokers or companies with an insurance division of their own.

${ }^{17}$ E.g. they could be held null and void; the insurer cannot invoke one or more core clasuses in good faith; they are interpretated narrowly to the disadvantage of the insurer.
} 
Third and most important in this context, a penetrating message could urge the insured to consider whether or not he should refrain from specific activities or from manufacturing specific products, to charge a higher price for his goods or services and the possibilities to get a more comprehensive coverage elsewhere (e.g. abroad). Moreover, defendants could (and should, I think) harp on this tune when they are sued in order to convince the court to be reluctant to create new liabilities. Professional organisations could try to persuade legislators to fix ceilings or take other appropriate measures to shut the uninsurable floodgates.

The latter is not necessarily a non-starter. Legislators are concerned about uninsurability of liability. For instance, in the area of transport law ceilings are quite common.

If neither the courts nor the legislators are sensitive to uninsurability, it is at least a strong indication that claims made-policies do not meet unsurmountable hurdles.

\section{Should claims made policies be challenged vigorously?}

\subsection{General observations}

It follows from the above that claims made-policies are rather unattractive, seen from the insured's perspective. It is true that they also have pros but, they mainly work against then. It is certainly possible to counterbalance the cons by one or more measures, set out 6 above. In the long run - if not from the very beginning - they will not bring much solace.

If claims made-policies are a necessity for the insurance industry to survive, one cannot expect insurers to remove essential protective clauses. This necessarily implies bad news for the insured: he may find himself empty handed, i.e. without insurance cover.

Bad news shows are not very popular. Legislators and courts in various countries raised serious obstacles to protect the insured. I briefly touched upon them above in point 2 and 3 . In this chapter, we should focus on this topic more carefully. Two questions deserve our attention: First, are the protective measures, required by various legislations, effective? If not, do they make sense? Second, how to judge claims made-policies, taking the pros and cons into account?

\subsection{The effectiveness of retroactive coverage and prospective coverage}

Belgian and Spanish legislation requires retroactive or prospective (or nose) coverage. See point 2 and 3 above. Dutch insurers tend to be of the same view, yet, the extension is rather limited in time. This begs the question: are they an effective solution?

The answer is clearly negative, at least on a general level. It is quite well possible that it will fill in gaps in specific cases. That is obviously a blessing for the insureds concerned, but irrelevant for the purpose of judging this type of insurance policy. The question as such remains open.

Claims made-policies are introduced to cope with the (potential) developments, briefly described above. Long tail is one of the key words, the phantom for insurers. Long really stands more than one, two or three years. This implies that a brief extension, either retrospectively or prospectively, does not solve the real problem. 
I fail to see why an ineffective requirement would convert an - as it is perceived unreasonably burdensome policy into an admissable one. In fact, it would be insult to injury for those who are truly hurt by claims made-insurances: insureds confronted with long tail claims. They would lack the legislator's help when they truly need it.

However, the legislator should not intervene, not even to ease their fate. He faces a "gorgon medusa": It is well known in Greek methodology that one should not cut off its head. The same is true here: solving the insured's difficulties by cutting the core of the claims made-policies creates severe difficulties for insurers. The remedy is worse than the disease.

\subsection{Premiums have been paid, so the insurer has to pay}

The French Supreme Court - and until recently the Spanish Supreme Court as well harped on another tune: the insured has paid premium. For that reason it would be utterly unfair if the insurer could withdraw from the contract and consequently from his obligation to pay his (former) insured.

The argument is fiercely criticised in France and in Spain but seems to be supported in the Netherlands. The better view seems the criticism. It is difficult to understand how insurers calculate a premium for new developments they cannot contemplate. This has nothing to do with the uncertainties they always and unavoidably face.

In many "normal" cases, the law of averages applies. For one insured, it is uncertain when and how often a labour accident will occur. In relation to all the insureds together, the figure will be rather stable from year to year. The same is true for other accidents, explosions, etc. Even if explosions rarely occur, (re)insurers will have suffienctly reliable figures to calculate the premium and to value the risk. Their calculation may turn out to be wrong and they may suffer a loss, but that is all in the game. The relevant parameters are known. In a worst case scenario, an insurer will face several events within a couple of years, triggering the financial limits of the relevant policies. The impact will be relatively limited. Again, in view of the law of averages, it is most unlikely that many such expensive claims will occur at same time.

This is quite different in connection with the developments briefly described above in point 1 . Whether statistics nor past experiences are available. The insurer has no concrete data to make an even rough calculation. It would be mere coincidence if his "guess" would near the truth. In brief, he cannot fix a premium and consequently not provide a cover.

The insurer faces a second difference, compared with "classical occurrences". If new developments appear on the scene, there is a fair chance that they will affect a great many insureds and consequently challenge the financial limits of each of them.

Some examples: case law widens the scope of the "duty of care concept" in relation to attorneys. This may well give rise to a considerable number of new claims, even more so if the new doctrine could also be applied to accountants and public notaries.

RSI, EMF or other "diseases" can be attributed to specific causes like keyboards, computer screens, etc. A Supreme Court holds that the manufacturer and the employer are liable towards the victim. The number of potential victims will probably be apocalyptically immense as is the number of insureds. 
I do not believe that these examples are unrealistic, let alone unjustifiable defaitism. It may turn out that the future is less dark (as I hope it will be), we ought to keep our eyes open.

One could remonstrate that new developments will affect claims made-insurers anyway.

E.g. the Dutch Supreme Court would held that employers are liable for RSI claims. Such a judgement will open the floodgates, as the DES case showed: after the judgement many thousands of claims were brought.

The observation as such is true, but cannot necessarily justify a ban of claims madepolicies altogether. First, the mere fact that insurers will face serious difficulties in specific doom scenarios does not mean that the same should be true on an even larger scale. Insurers will hopefully survive catastrophic events as in the RSI example. Having to pay out would have a detramental effect on them, irrespective of the magnitute of apocalyptical developments.

Furthermore, even in the RSI example, they could possibly keep their exposure within bearable limits if the policy only provides cover for claims based on actual damage and does not provide a circumstance clause nor an extended notification period ${ }^{18}$.

In the RSI example they could disregard claims based on damage that does not yet exist or occurred on the expiring date, assuming that their serial clause does not queer the pitch $^{19}$.

\subsection{Accidents}

Claims made-policies find their justification in fear for an uncertain future. They have nothing to do with classical damage like explosions and labour accidents. Yet, they may affect the same.

Company $\mathrm{C}$ has a claims made-policy with insurer $\mathrm{A}$ without an extended reporting period. $C$ concludes a new agreement with $B$, without retroactive coverage. The night before the new agreement comes into force, an explosion occurs. This has nothing to do with the increasing liability law. It is merely ordinary bad fortune. Claims cannot be made in due time. Strictly speaking, $\mathrm{C}$ would find himself without insurance.

It would not be fair and equitable to deprive $C$ of coverage. If not for other reasons, because one may take it for granted that in this particular case he actually paid - or at least assumed to have paid - a premium for this kind of occurrences.

The outcome might be different if $\mathrm{C}$ deliberately opted for a policy without a retroactive coverage or an extended reporting period. Whether $C$ will regret such a choice depends on the circumstances of each specific case, for example the premium paid and the question of whether or not the parties contemplated the issue at stake.

\footnotetext{
${ }^{18}$ To be defined in more detail.

${ }^{19}$ An issue that would deserve more attention, but would go far beyond the scope of this contribution. It is a fascinating and extensive topic on its own.
} 


\subsection{Reasonable expectation of the insured and statements of the insurer}

\subsubsection{The expectation that claims will be covered}

The issue of the insured's reasonable expectation has already been touched on in point 6 above. Many US courts harped on this tune. It is desirable if not required to inform the insured about the meaning and consequences of claims made-policies, unless the insured is familiar or at least acquainted with this phenomenon or is assisted by a broker. Several policies are very explicit on the issue, mentioning it on the cover page of the terms and conditions in bold.

It is open to debate whether the statement should stress - as they sometimes do - that questions were to be addressed to the broker. The benefit clearly is that the latter will often inform the insured properly. In such cases, the insured can no longer plead his ignorance, i.e. wrong expectation. If, however, the information would be incorrect - which is not within the insurer's scope of control - it will probably be attributed to the insurer.

It could also be argued that a broker who does not provide adequate information to the insured is liable. In such cases, the claims made insurer will be well off, but the broker's insurer will have to compensate the insured. On a larger scale the insurers would not gain from claims made in such scenarios.

\subsubsection{Imprecise statements about the "need for claims made-policies"}

Insurers ${ }^{20}$ tend to explain why they switch from loss occurrence to claims madepolicies. Their communication is sometimes rather general, perhaps even exaggerated or, even worse, incorrect.

For example, some insurers seem to stress that the number of claims is rising already now. To stick to the Netherlands, that is only true in specific areas. Generally speaking the number is dropping.

A related issue is that statements are sometimes rather incoherent or contradictory. The US National Conference of State Legislatures refers to "terminology and accounting methods used by the industry which are often quite different from the general understanding of such concepts. For example, reports of industry losses for 1985 have been calculated at anywhere from a $\$ 5.5$ billion loss to a $\$ 1.7$ billion profit." 21

Such statements are unnecessarily dangerous. First, insurers have a rather appealing and convincing story: well founded fear for the future and a substantial rise in numbers and size of claims in several fields ${ }^{22}$. Secondly, and more importantly, insurers run the risk of courts using them to attack the essence of clains made-policies ${ }^{23}$.

\footnotetext{
${ }^{20}$ I do not touch upon the consequences of communications from associations of insurers.

${ }^{21}$ Resolving the liability crisis, part II no 6 page 5.

${ }^{22} \mathrm{I}$ leave aside whether this is true for every country. If not, the need for claims made-policies is perhaps not yet existent.

${ }^{23}$ I do not touch upon the techniques. They may be different in the respective countries. It could be argued that slight exaggeration is merely transparant sales talk, rather usual in business transactions.
} 


\subsection{Societal responsibility of insurers to cover uninsurable risks}

Several scholars and even parts of the (Dutch) insurance industry are of the opninion that insurers have a responsibility to provide insurance policies, even if the premiums cannot be fixed adequately. This should be their contribution to the needs of society. The argument sounds unjustified and rather unwise.

One can hardly think of any valid reason why insurers would have any other mission than other members of industry: to put products or services on the market with the purpose to make money. If those products or services are not appreciated, they will not be sold. In such a case, it is up to the provider to make a choice between adapting the product or service or refraining from putting it on the market. He is certainly not obliged to do the former.

Cars with ABS or airbags are clearly safer than cars without. The argument that the manufacturer would have to fit out its cars with this without getting paid for it, would be foolish. The parallel with loss occurrence-policies for which the insurer cannot calculate the premium is striking.

Similarily, a baker or a farmer would not be obliged to sell his products to a poor man for a price well below the normal price. A civilised society will protect a man from starving, but this does not imply that the baker or farmer must do so.

The argument could well - and even better - be reversed: society needs financially solid insurers, i.e. insurers not exposing themselves to irresponsible risks.

A variation on the above theme is that insurers make a lot of profit on other insurances. They can afford to make losses on insurance liability. The argument fails on a similar ground, even if it would be true that the profits would be enough to compensate possible future losses ${ }^{24}$.

Let us assume that the prices of domestic fuel oil - belonging to the first necessities of life - would be so high that the average consumer would be unable to pay them. This would not mean that the oil company would have to decrease them because it is making a lot of profit on petrol. Why would this be different for insurers?

This is not to say that legislators ought to refrain from appropriate actions. Tort law reform might well be desirable. One could also imagine that the national States would offer complementary insurance coverage. This topic certainly deserves our attention ${ }^{25}$.

\subsection{Unfair contracts and the freedom of contract}

It has already been said: claims made-policies are not ideal. Despite the obvious disadvantages for the insured, they are not unfair. Let me elaborate on this topic:

The freedom of contract is one of the pillars of modern contract law. It is up to the parties in the contract to decide the terms and conditions of their agreements. They have

\footnotetext{
${ }^{24}$ Again, we have to reckon with apocalyptical scenarios.

${ }^{25}$ See J. Spier, in: J. Spier, ed. The Limits of Liability pp $117 \mathrm{ff}$.
} 
to fix the quid pro quo. The courts do not formally interfere to find out whether the price is equitable in relation to what the other party gets in return. In short, we do not have to bother ourselves with the iustum pretium question (the adequacy of consideration). A general test of fairness has to be rejected ${ }^{26}$.

Limitation or restiction of the scope of liability is widely recognised in business transactions. Sellers usually exclude their liability in their general terms and conditions. This is a well accepted business practice. As a general rule, such clauses will stand ${ }^{27}$.

Nevertheless, construing claims made-policies against the insurer, such that he would have to pay despite the clear wording and restrictions of the policy, would be unreasonably disadvantageous for the insurer. He would have to pay, in spite of the fact that he did not get any premium in return. It cannot be argued that such a solution would be fair, let alone that there would be an equilibrium between the interests of both parties. Compared to the situation where an insured would not get paid damage for risks for which he did not pay premium, it would evidently be far less balanced.

It should be stressed that the issue of "unfairness" does not play a role if the insured had a real choice offered either by his insurer or his competitors. In that case he voluntarily entered into the claims made contract and does not have reason to complain.

The same is true if such a choice did not exist, but for another reason. Usages and practices in the trade have to be taken into account. They generally reflect the behaviour of reasonable parties ${ }^{28}$. In other words, the fact that not even one major insurer is prepared to offer loss occurrence-policies is a strong indication that such behaviour is reasonable.

The above does not include the fact that a transaction which is clearly deleterious might be thought to indicate that it was not really accepted ${ }^{29}$. That, however, is about the consent part $^{30}$. For the reasons set out above, I do not believe that claims made-policies are "clearly deleterious". Furthermore, if the insured is sufficiently aware - or should have been aware - of the consequences, I see no reason why examination of the consent would render the contract invalid.

\subsection{Limited consequences for the insurer}

The mere fact that the financial consequences of a the claim at stake are relatively limited is of no importance.

$\mathrm{X}$ manufactures a new drug. $\mathrm{X}$ is the only manufacturer. After a couple of years, research shows that the drug causes serious diseases. Quite a number of children fall ill.

\footnotetext{
${ }^{26}$ That is also the approach of art. 3.10 of the Unidroit Principles for International Commercial Contracts, be it with few exceptions. See for details O.A. Haazen, The principle of gross disparity en misbruik van omstandigheden, in: Europees contractenrecht, BW-krant jaarboek 1995, pp 13 ff.

${ }^{27}$ See O. Lando and H. Beale (ed.), Principles of European Contract Law, Part I pp. 147 and 150.

${ }^{28}$ Principles of European Contract Law, o.c. pp. 62/63.

${ }^{29}$ Hugh Collins, The Law of Contract (2nd ed.) page 254.

30 Art. 3.10 of the Unidroit Principles for International Commercial Contracts refers inter alia to ignorance and inexperience.
} 
This is the kind of developments insurers aim to get rid of by introducing claims madepolicies. Yet, the total amount involved is relatively limited as $\mathrm{X}$ is the only manufacturer. In a worst case scenario, the insurer would have to pay the entire financial limit.

It would be pure capriciousness to eliminate $X$, just because he is the only manufacturer, while one would stick to the essence of claims made if there were more.

It could possibly be argued that the insured may reasonably expect non-disastrous developments to be covered, despite the wording showing the contrary, because the insurer will always take a certain margin for unforeseen events. Whether or not such an argument has to be honoured depends on the merits of the case to be solved. For the same reason as just mentioned, one must be reluctant to accomodate the insured in this respect. If not for other reasons, because it seems impossible to draw a borderline.

\section{Conclusion}

1. In several areas (product, environmental and professional liability, including $\mathrm{d} \&$ o and occupational diseases, there are compelling grounds to introduce claims made-policies.

2. Claims made-policies have advantages and disadvantages, compared to loss occurrencepolicies. Seen from the insured's point of view, the disadvantages of claims madepolicies prevail; from the insurer's angle it is the advantages.

3. There are several tools to restrict the disavantages for the insured. The very greater part is not much help. Only unconditional and non restricted retroactive cover, together with a generous extended notification period and circumstance clause, would truly provide relief. However, given the necessity of introducing claims made-policies, it is most unlikely that insurers will continue to be prepared to offer the same. Moreover, they should not do so since it would put them back to square one ${ }^{31}$.

4. As a general rule, claims made-policies are not unfair, not even if they restrict retroactive and prospective coverage (as they should). Exceptions may apply as in the case of "classical damage", occurring just before the elapsing of the contract, if the damage would not be covered under any policy.

5. Reasonable expectations of the insured could place a spoke in the wheel. To be on the safe side, he should be informed about the meaning and consequences of claims made, including the possibility of gaps in his coverage in case of subsequent insurers. This may be done either by the insurer or the broker. This is not necessary, if the insured is sufficiently familiar with insurance matters.

Communication in general, and even more so information about the background and justification of claims made-policies, should be well considered. Slight exaggeration would possibly be allowed as is usual with commercial selling statements.

6. The question of how often posed to find the right balance between the legitimate desire of insurers and the necessity of prescribing an adequate matching of liability and its coverage by insurance is, if I may say so, awkward.

${ }^{31}$ In fact even worse. See 5 above. 
It is based on the wrong assumption that claims made-policies are unfair or unreasonably burdensome. It seems to suggest that an insurer should throw himself in an unfathomable depth without collecting adequate premiums. After all, if the future would truly have many unforeseeable nasty surprises in store, for which the insured did not pay a premium (because it could not be calculated), the insurer alone would bear the entire fate of the future. He would be like Atlas, whose heroic work hardly contributed to the wealth of nations.

\section{REFERENCES}

A.M. ALVAREZ-BARON, Spain's claims-made crisis, (1994) 8 Int. ILR $316 \mathrm{ff}$.

American Bar Association, Report of the Commission to Improve the Liability Insurance System, 1989.

ANGELL, J.; Claims made policies or occurrence poli-cies in civil liability insurance in Spain: announced legislative changes, (1994) IJIL 191/ 192.

ANGELL, J.; Claims made policies or occurrence policies in civil liability insurance: a Spanish judicial perspective, (1994) IJIL 112 e.v.

ANGELL, J.; The new Spanish law for the regulation and supervision of private insurance, (1996) IJIL 93 e.v.

ASHTON, R. S. and DERRINGTON; The Law of Liability Insurance, Butterworths, Sydney 1990.

BLAIR, R. D. and MAKAR, S. D.; Perspectives on the Insurance Crisis, 5 Yale Journal on Reg. 427 e.v.

BOLT, A. T., SPIER, J. and HAAZEN, O. A.; De uitdijende reikwijdte van het aansprakelijkheidsrecht uit onrechtmatige daad, preadvies Nederlandse Juristen-Vereniging 1996, W.E.J. Tjeenk Willink, Zwolle.

CLARKE, M. A.; The Law of Insurance Contracts, 2nd ed., LLP, Londen 1994.

CLARKE, M. A.; The Law of Insurance Contracts, first supplement to the second edition, LLP, Londen 1996.

COUSY, H. and SCHOORENS, G.; De nieuwe wet op de landverzekeringsovereenkomst, Kluwer Rechtswetenschappen, België.

FAURE, M. G.; The Limits to Insurability from a Law and Economics Perspective, The Geneva Papers on Risk and Insurance No. 77 (October 1995) pp 454 ff.

FAURE, M. G. and HARTLIEF, T.; (ed.), Verzekering en de groeiende aansprakelijkheidslast, Kluwer, Deventer 1995.

FONTAINE, M.; Claims made policies under Belgian law, (1994) IJIL 128/129.

FRAME, C. M.; "Claims-made" Liability Insurance: Closing the Gaps with Retrocactive Coverage, Temple Law Quarterly (Vol. 60 1987) 165 ff.

FUHRER, S.; Die Vermögensschaden-Haftpflichtversicherung, Schulthess Polygraphischer Verlag, Zürich 1988.

GROUTEL, H.; L'extermination des clauses limitatives dans le temps de la garantie des assurances de responsabilité, Resp. civ. et assur. 1991 Chron. 4.

HAGOPIAN, M.; France: The Supreme Court Rules that "Claims-Made" Coverage is a Nullity, (1994) IJIL 52/53. 
HANKEY, B.; Claims Made Policies and Choice of Law in the European Union, (1994) 7 Int. ILR $267 \mathrm{ff}$.

HAWKE, F.; Notification of Circumstances un-der Claims Made Policies: Some Observations upon the Scope and Operation of the Insurance Contracts Act 1984 (Cth), (1994) 6 Insurance Law Journal, pp $252 \mathrm{ff}$.

HENDERSON, F. R. C.; Insurance Law, The Michie Company, Charlottesville (USA) 1989.

HENDERSON, F. R. C.; The Doctrine of Reasonable Expectations in Insurance Law After Two Decades, Ohio State Law Journal (Vol. 51:823 1990).

HOLSBOER, J. H.; Insurability and Uninsurability: An Introduction, The Geneva Papers on Risk and Insurance No. 77 (October 1995) pp $407 \mathrm{ff}$.

Industrial Liability Policies in the countries of the EC and in Austria and Switzerland, Münchener Rückversicherungs-Gesellschaft, München 1991. Jurisclasseur responsabilité civile et assurances.

KEETON, R. E. and WIDISS, A. I; Insurance Law, West Publishing, St. Paul 1988.

LAMBERT-FAIVRE, Y.; Droit des assurances (9th ed.), Dalloz, Parijs 1995.

LANDO, O. and BEALE, H.; (ed.), Principles of European Contract Law, Part I.

Martinus nijhhoff, Dordrecht/Boston/London, 1995.

LEVEL, P.; Assurance de reponsabilité: Nullité de la clause exigeant que la réclamation du tiers lésé soit formulée avant l'expiration de la police, JCP 1991 Etudes 62 pp $287 \mathrm{ff}$.

MCMAHON, M. J.; Event Triggering Liability Insurance Coverage as Occurrence within Period of Time Covered by Liability Insurance Policy where Injury or Damage is Delayed-Modern Cases, 14 ALR5th 695.

MEUWLY, J. B.; La durée de la couverture d'assurance privée, Editions universitaires Fribourg, 1994.

OSTRAGER, B. R. and NEWMAN, T. R.; Handbook on Insurance Coverage Disputes, 7th ed. Prentice Hall Law \& Business 1994.

PERRY, C. K. and DRUTCHAS, G. G.; Claims-Made Insurance: A Primer of Benefits and Pitfalls, Michigan Bar Journal 1988, pp $127 \mathrm{ff}$.

Resolving the Liability Insurance Crisis, State Legislative Activities in 1986, National Conference of State Legislatures, Washington 1986.

VAN SCHOUBROECK, C.; Aansprakelijkheidsverzekering, in: De nieuwe wet op de verzekeringsovereenkomst, wat nu in de praktijk? pp $173 \mathrm{ff}$, Centrum Verzekeringswetenschap KU Leuven Cahiers 1993/3.

SHELLER, M.; "Claims Made": the Ausiralian Experience, (1994) IJIL $188 \mathrm{ff}$.

SPÄTE, B.; Haftpflichtversicherung, AHB-Kommentar, C.H. Beck, München 1993.

SPIER, J.; and HAAZEN O. A.; Aansprakelijkheidsverzekeringen op claims made-basis, Kluwer, Deventer 1996.

SUTTON, K.; Insurance Law in Australia, 2nd ed., The Law Book Company 1991.

TEICHLER, M.; Berufshaftpflichtversicherungen, Verlag Peter Lang, Frankfurt am Main 1985.

WANSINK, J. H.; De algemene aansprakelijkheidsverzekering (2nd ed.), W.E.J. Tjeenk Willink, Zwolle 1994.

WANSINK, J. H.; Claims made policies and the test of legality in Europe, AIDA Pollution Insurance Bulletin augustus 1995, pp 3/4. 